\title{
ORAL PAPILLARY SQUAMOUS CELL CARCINOMA: \\ CASE REPORT AND LITERATURE REVIEW
}

\section{CARCINOMA DE CÉLULAS ESCAMOSAS PAPILAR ORAL: RELATO DE CASO E REVISÃO DE LITERATURA}

\author{
Lísia Daltro Borges Alves', Alessandra Laís Pinho Valente Pires², Tarsila de Carvalho Freitas \\ Ramos $^{3}$, Márcio Campos Oliveira ${ }^{4}$,Valéria Souza Freitas ${ }^{5}$
}

\section{Resumo}

carcinoma de células escamosas papilar é um tumor que acomete o trato aerodigestivo superior e raramente afeta a cavidade oral. $\bigcirc$ objetivo do presente estudo foi relatar um caso de carcinoma de células escamosas papilar em cavidade oral e revisar a literatura a respeito. Paciente, sexo masculino, 73 anos, apresentando duas lesões intraorais com 3 meses de evolução. Havia uma lesão exofítica, úlcero-vegetativa, medindo 1,5 cm em rebordo alveolar (assoalho bucal) do lado esquerdo e uma lesão ulcerada na região retromolar esquerda medindo I cm. Além disso, havia um linfonodo endurecido e sintomático no nível I B do lado esquerdo, medindo $4 \mathrm{~cm} \times 3 \mathrm{~cm}$. As duas lesões intraorais foram biopsiadas e a que acometia o rebordo alveolar (assoalho bucal) foi diagnosticada como carcinoma de células escamosas papilar - composto por células atípicas, basaloides e em disposição papilar. No momento do estadiamento, o tumor apresentava $4 \mathrm{~cm} \times 6 \mathrm{~cm}$, sendo estadiado como T3N2aM0 (IV-A) e o tratamento empregado foi quimioterapia associada à radioterapia. Após 2 anos de acompanhamento, o paciente encontra-se vivo, sem evidência de doença, metástase em linfonodos ou a distância. Concluise, portanto, que carcinoma de células escamosas papilar é um tumor raro na cavidade oral, com poucos casos relatados. $\bigcirc$ presente relato destaca a importância do exame histopatológico para o diagnóstico preciso e seu papel na determinação de tratamentos e prognósticos adequados.

Palavras-chave: Patologia Bucal, Neoplasias de Cabeça e Pescoço, Neoplasias Bucais.

\begin{abstract}
Papillary squamous cell carcinoma is a tumor that affects the upper aerodigestive tract, but rarely the oral cavity. The aim of this study is to report a case of oral papillary squamous cell carcinoma and to review the available literature. We present a case of a 73-year-old man patient with two intraoral lesions with three-month evolution. An ulcerated exophytic lesion measuring $1.5 \mathrm{~cm}$ was detected in the left alveolar ridge region/mouth floor and an ulcerated lesion in the left retromolar region measuring I cm. Moreover, we identified a symptomatic hardened lymph node on the level IB of the left side, measuring $4 \times 3 \mathrm{~cm}$. Both intraoral lesions were biopsied and the one in the alveolar ridge/mouth floor was diagnosed as papillary squamous cell carcinoma - composed of atypical cells, basaloids and in papillary disposition. At the time of staging, the tumor had $4 \times 6 \mathrm{~cm}$ being staged as T3N2aMO (IV-A) and the employed treatment was chemotherapy associated with radiotherapy. After two years of follow-up, the patient is alive and without evidence of the disease, lymph node or distant metastases. Therefore, the papillary squamous cell carcinoma is a rare tumor in the oral cavity with few reported cases. This case report emphasizes the importance of histopathological examination for the accurate diagnosis and its role in determining appropriate treatments and prognosis.
\end{abstract}

Keywords: Oral Pathology, Head and neck neoplasms, Mouth Neoplasms

\footnotetext{
I. Dentistry, Department of Health Sciences, State University of Feira de Santana, Feira de Santana, Bahia, Brazil.

2. Dentistry, M.Sc. in Public Health, Department of Health Sciences, State University of Feira de Santana, Feira de Santana, Bahia, Brazil.

3. Dentistry, M.Sc. in Oral Pathology, Department of Health Sciences, State University of Feira de Santana, Feira de Santana, Bahia, Brazil.

4. Dentistry, Ph.D. in Oral Pathology, Department of Health Sciences, State University of Feira de Santana, Feira de Santana, Bahia, Brazil.

5. Dentistry, Ph.D. in Oral Pathology, Department of Health Sciences, State University of Feira de Santana, Feira de Santana, Bahia, Brazil.
}

\section{How to cite this article:}

Alves LDB, Pires ALPV, Ramos TCF, Oliveira MC, Freitas VS. Oral papillary squamous cell carcinoma: case report and literature review. Nav Dent J. 202 I; $48(2)$ :.80-85. 


\section{INTRODUCTION}

Papillary squamous cell carcinoma (PSCC) is a Squamous Cell Carcinoma (SCC) variant (I) that affects the upper aerodigestive tract $(2,3)$, especially larynx, oropharynx and nasopharynx $(3,4)$. The oral cavity is an atypical location for this tumor $(5,6)$, with approximately 70 cases reported in the literature (2). Its etiology remains unknown and seems to involve other carcinogenic agents besides tobacco (7), similarly to other tumors that affect the oral cavity (8).

PSCC commonly presents multiple, delicate filiform, finger-like papillary projections with fibrovascular cores or broad-based bulbous to "cauliflower-like" exophytic growth with rounded projections, measuring from $2 \mathrm{~mm}$ to $4 \mathrm{~cm}$ (2). It mainly affects men aged between 50 and 70 years old (3). The main differential diagnosis are Verrucous Carcinoma and SCC (9).

The histopathological examination is essential to a proper diagnosis for the disease ( 10$)$ and usually shows a papillary growth, with thin fibrovascular cores, covered by basaloid cells or dysplastic squamous cells with minimal or no keratinization (I I).

Treatment for PSCC is usually surgical and generally has a good prognosis, with rare occurrences of metastases, despite the high rates of recurrence $(3,7,9)$. Thus, this study aims to report a case of oral PSCC and to review the available literature.

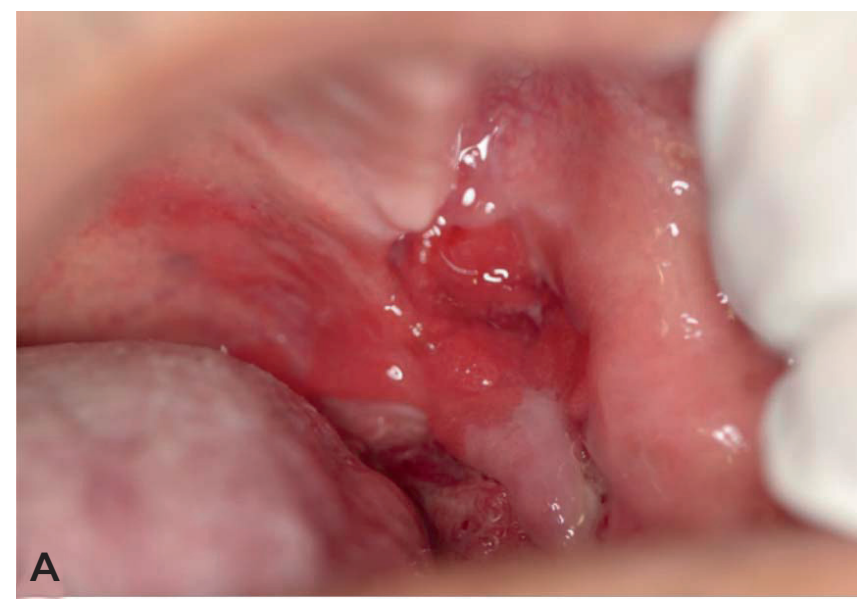

\section{CASE REPORT}

A 73-year-old man was referred to a Center of Oral Injuries at the State University of Feira de Santana, Brazil, in 2017, complaining of "an inflammation that had been bothering him for three months". He had been a smoker for 52 years (two packs of industrialized cigarettes per day), reported alcohol consumption for the previous 12 years (kept the habit for 40 years), was edentulous and report no other comorbidities.

Extraoral physical examination showed a symptomatic hardened lymph node on the level IB, in the left side, measuring $4 \times 3 \mathrm{~cm}$. On intraoral examination, we observed an ulcerated exophytic lesion, with firm consistency, rough surface, reddish color, measuring $1.5 \mathrm{~cm}$, in the alveolar ridge region, extending to the mouth floor (Figure I). In addition, an ulcerated lesion was observed in the left retromolar region, with $1 \mathrm{~cm}$ (Figure I).

The patient underwent incisional biopsy of both lesions, with clinical suspicion of SCC. The histopathological sections examined and stained with hematoxylin and eosin from the lesion located on the alveolar ridge/ mouth floor revealed malignant neoplasia characterized by proliferation of malignant cells with basaloid morphology and arranged in papillary projections (Figure 2). These cells exhibited considerable atypia in all planes of the epithelium and invaded the subjacent stroma. Despite the impossibility of performing

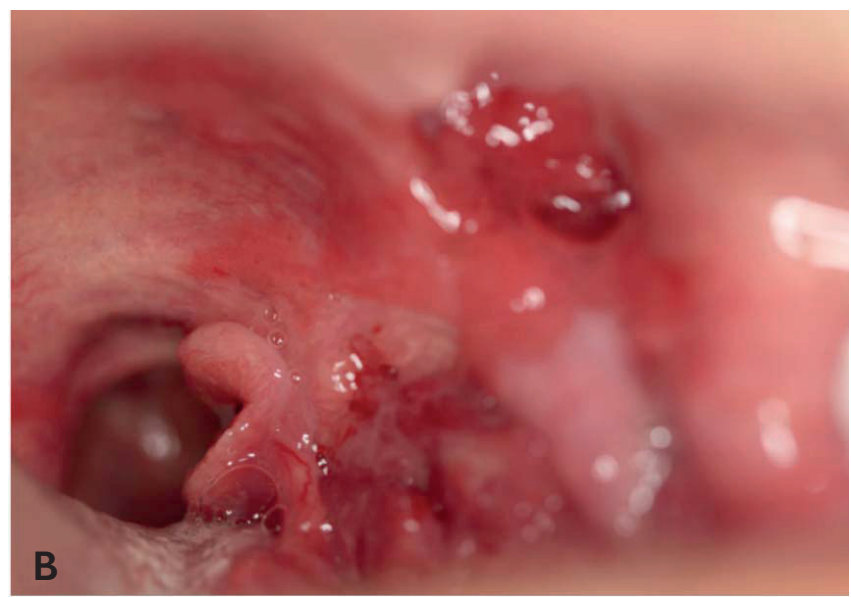

Figure I - (A) Ulcerated exophytic lesion in the alveolar ridge region. (B) Ulcerated lesion in the left retromolar region. 

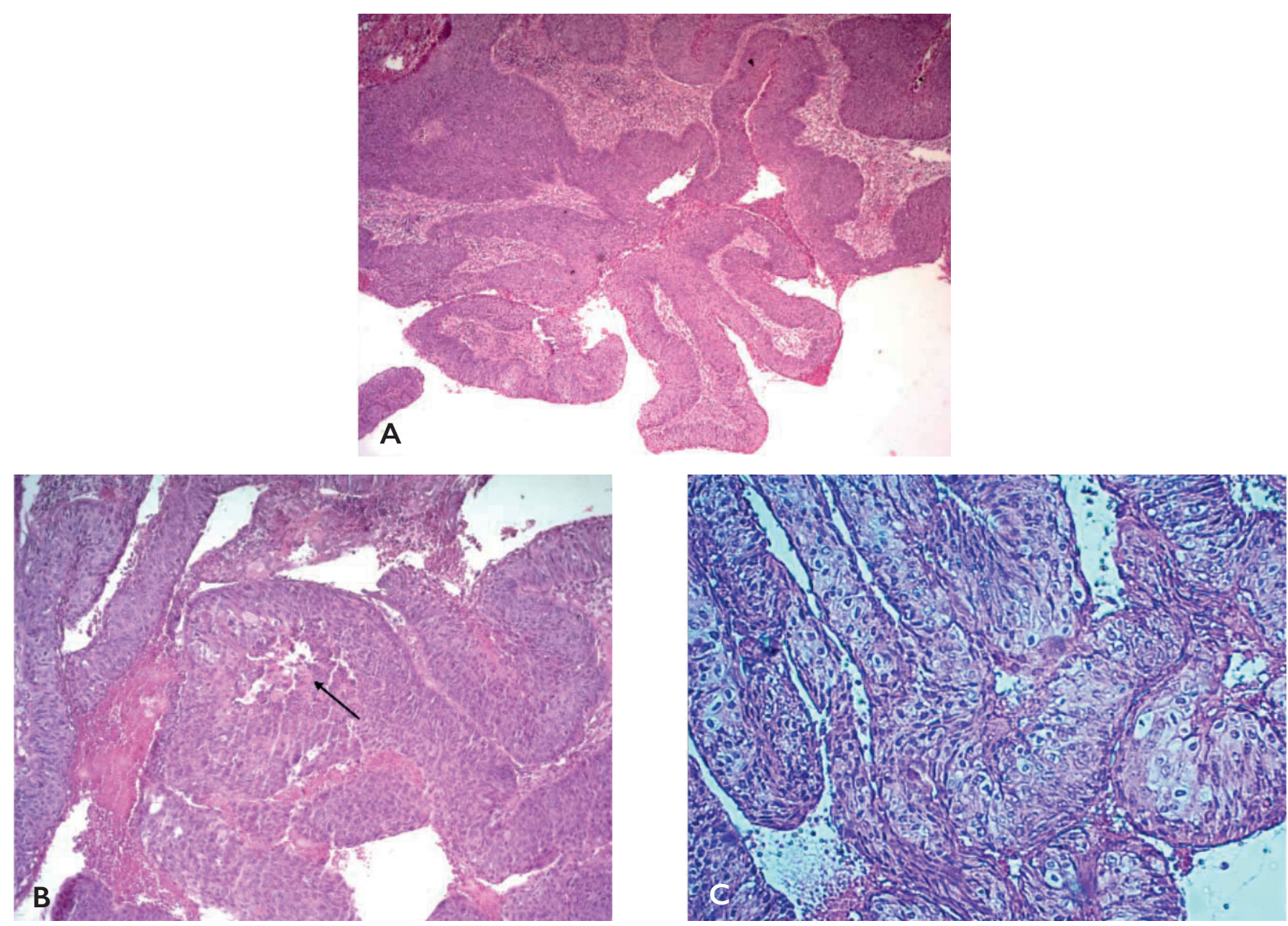

Figure 2 - (A) Photomicrograph showing papillary projections with proliferation of malignant cells in basaloid morphology and dysplastic squamous cells supported for thin fibrovascular cores (HE*, $5 \times)$. (B) Island of malignant cells with central necrosis (arrow) (HE*, I0x). (C) Proliferation of cells with basaloid morphology, with atypia - nuclear hyperchromatism, cellular and nuclear pleomorphism and numerous mitosis (HE*, 20x). *Hematoxylin and eosin.

immunohistochemical analysis for pl6, the morphological aspects were compatible with PSCC, allowing such histopathological diagnosis. Furthermore, the histopathological findings of the retromolar lesion were compatible with carcinoma in situ.

The patient was referred to High Complexity Unit in Oncology in Feira de Santana for treatment. At this point, the lesion measured $4 \times 6$ $\mathrm{cm}$, extending $1 \mathrm{~cm}$ to the floor of the mouth, sparing the tongue edge; it also extended to the soft palate on the left, sparing the uvula; and it was not possible to evaluate the posterior limit. Lymph node enlargement remained with $4 \times 3$ $\mathrm{cm}$ in left level IB, semi-fixed to the mandible, but became painless. Considering these data, the tumor was staged as T3N2aM0 (IV-A). Surgery was contraindicated due to the advanced stage disease and chemotherapy ( 7 weekly cycles of Cisplatin $40 \mathrm{mg} / \mathrm{m} 2$ ) with radiotherapy (70 Gy in 35 fractions) was performed. After two years of follow-up, the patient is alive without evidence of disease.

This study was approved by the university research ethics committee (CAAE: 0086.059.000-08) and the patient signed the free and informed consent form.

\section{DISCUSSION}

Oral PSCC is a rare tumor that differs from SCC especially due to its cellular arrangement and constitution, which mostly presents a favorable prognosis. The expansion of knowledge about this tumor, through new studies, as well as this case report, are essential to support clinicians, 
Table I - Clinical features of papillary squamous cell carcinoma cases, published in Medline and PubMed until March 4, 2020.

\begin{tabular}{|c|c|c|c|c|c|c|c|}
\hline Reference & $\begin{array}{l}\text { Type } \\
\text { of study }\end{array}$ & Sample & Sex & $\begin{array}{c}\text { Mean } \\
\text { age } \\
\text { (range) }\end{array}$ & Location & Treatment & Outcome/Follow-up \\
\hline $\begin{array}{l}\text { Present case, } \\
2021\end{array}$ & CR & 01 & OI(M) & $73 y$ & Alveolar ridge/Mouth floor & $C T+R T$ & $\begin{array}{l}\text { No } \\
\text { REC/02 years }\end{array}$ \\
\hline $\begin{array}{l}\text { Alotaiby et al., } \\
2018(I I)\end{array}$ & CR & $\mid 01$ & |01(M) & $85 y$ & Tongue & s & $\begin{array}{l}\text { No } \\
\text { REC/03 months }\end{array}$ \\
\hline $\begin{array}{l}\text { Xiaofeng;'Wei, } \\
2016 \text { (12) }\end{array}$ & CR & 01 & $01(F)$ & $63 y$ & Buccal mucosa & s & $\begin{array}{l}\text { No } \\
\text { REC } 103 \text { months }\end{array}$ \\
\hline $\begin{array}{l}\text { Ding et al., } \\
2013(2)\end{array}$ & RS & 12 & $\begin{array}{l}\text { 07(F); } \\
\text { 05(M) }\end{array}$ & $\begin{array}{l}72.9 y \\
(53-83)\end{array}$ & $\begin{array}{l}\text { 04(Buccal mucosa);03(Gingiva); } \\
\text { O2(Lower lip);Ol(Palate); } \\
\text { Ol(Tongue);OI(Mouth floor). }\end{array}$ & s & $\begin{array}{l}02 \text { REC and death/ } \geq 20 \text { and } 24 \text { months; } \\
02 \text { REC and alivel } \geq 28 \text { and } 36 \text { months; } \\
01 \text { death/48 months }\end{array}$ \\
\hline $\begin{array}{l}\text { Fitzpatrick et al., } \\
2013(15)\end{array}$ & RS & |61 & 28(F); & $\begin{array}{l}74 y \\
(27-99)\end{array}$ & 61(Gingiva) & NA & NA \\
\hline $\begin{array}{l}\text { Bao et al., } \\
2012(16)\end{array}$ & RS & 56 & $\begin{array}{l}\text { 21(F); } \\
35(M)\end{array}$ & $\begin{array}{l}66.6 y \\
(35-86)\end{array}$ & 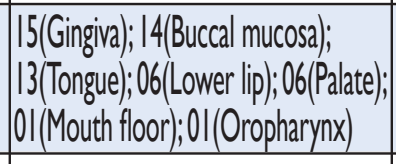 & ; $N A$ & NA \\
\hline $\begin{array}{l}\text { Terada, } \\
2012(6)\end{array}$ & CR & 01 & ol(M) & $70 y$ & (Gingiva) & s & $\begin{array}{l}\text { No } \\
\text { REC/03 months }\end{array}$ \\
\hline $\begin{array}{l}\text { Russell et al., } \\
2011 \text { (3) }\end{array}$ & RS & 52 & $\begin{array}{l}\text { I6(F); } \\
36(M)\end{array}$ & $\begin{array}{l}65 y \\
(38-84)\end{array}$ & $\begin{array}{l}\text { |9(Laryngopharynx); } \\
\text { 18(Oral cavity);08(Sinonasal } \\
\text { tract);07(Oropharynx) }\end{array}$ & $\begin{array}{l}\text { Oral cavity } \\
\text { tumors: } 13(S) \text {; } \\
05(S+R T)\end{array}$ & $\begin{array}{l}03 \\
R E C / 26 \text { months }\end{array}$ \\
\hline $\begin{array}{l}\text { Terada, } \\
2011(5)\end{array}$ & CR & 01 & $01(F)$ & $73 y$ & Gingiva & s & $\begin{array}{l}\text { No } \\
\text { REC/03 months }\end{array}$ \\
\hline $\begin{array}{l}\text { Marques et al., } \\
2009(13)\end{array}$ & CR & 01 & $01(F)$ & $80 y$ & Tongue & s & $\begin{array}{l}\text { No } \\
\text { REC106 months }\end{array}$ \\
\hline $\begin{array}{l}\text { Khan et al., } \\
2005(10)\end{array}$ & CR & 01 & $01(F)$ & $72 y$ & Gingiva & s & NA \\
\hline $\begin{array}{l}\text { Takeda et al., } \\
2001(14)\end{array}$ & CR & 02 & O2(M) & $\begin{array}{l}70 y \\
(68-72)\end{array}$ & $\begin{array}{l}\text { OI(Mouth floor); } \\
\text { Ol(Soft palate) }\end{array}$ & s & $\begin{array}{l}\text { No } \\
\text { REC/NA }\end{array}$ \\
\hline $\begin{array}{l}\text { Suarez et al., } \\
2000(8)\end{array}$ & RS & 38 & NA & $\begin{array}{l}66 y \\
(24-89)\end{array}$ & $\begin{array}{l}\text { 17(Larynx); II(Sinonasal tract); } \\
\text { 05(Oral cavity and oropharynx); } \\
\text { 05(Nasopharynx) }\end{array}$ & $\begin{array}{l}35(S+R T) ; \\
03(S+R T+C T)\end{array}$ & NA \\
\hline $\begin{array}{l}\text { Ishiyama et al., } \\
1994 \text { (7) }\end{array}$ & RS & 52 & $\begin{array}{l}\text { 24(F); } \\
\text { 28(M) }\end{array}$ & $\begin{array}{l}N A \\
(40->90)\end{array}$ & $\begin{array}{l}\text { 20(Alveolar ridge); } 13 \text { (Buccal mu- } \\
\text { cosa); I (Mouth floor or tongue); } \\
\text { 08(Others) }\end{array}$ & $\begin{array}{l}\text { 49(S);02(RT); } \\
\text { Ol(Refusal of } \\
\text { treatment) }\end{array}$ & $\begin{array}{l}17 \text { REC/NA; } \\
04 \text { Death/NA }\end{array}$ \\
\hline
\end{tabular}

CR, Case report; RS, Retrospective study; M, Male; F, Female; NA, Not available; y, years;

$\mathrm{CT}$, Chemotherapy; RT, Radiotherapy; S, Surgery; REC, Recurrence 
stomatologists and pathologists in future diagnoses.

A literature review was made to identify the cases already published until March 4, 2020. The search was conducted in Medline and PubMed, with the term "papillary squamous cell carcinoma" without year of publication restriction, until the date of the search. Also, a manual search and cross-reference of eligible articles was performed. We included human studies published in English, with full text available for download; regarding the types of accepted studies, we included case reports and retrospective observational studies. In total, 13 studies were identified, of which seven were case reports $(5,6,||-\mid 5)$ and six were retrospective observational studies $(2,3,7,9,16,17)$ (Table I).

Studies showed that the PSCC has a predilection for males, agreeing with the case reported by this paper $(3,7,16)$. In this context, Mehrad et al. (2013) reported 48 cases of PSCC and identified a general ratio of men to women of 2.7: I (4). However, Mehrad et al. (20|3) and Ding et al. (20|3) observed a prevalence in women when considering only those that affected the oral cavity $(2,4)$.

Regarding age, the subject of this study is above the average age reported by the literature, which is from 50 to 70 years $(3,4,7,18)$. However, other cases have reported people above this age group, such as Marques et al. (2009) and Alotaiby et al. (20|8), who reported cases aged 80 and 85 years, respectively $(12, \mid 4)$.

The lesion diagnosed as PSCC was located in the left alveolar ridge/mouth floor, agreeing with most cases reported by Ishyama, et al. ( 1994), that identified 20 cases on alveolar ridge (3). The literature describes that this pathology usually presents as a single lesion (2), differing from this study, which presented two lesions in the oral cavity, one diagnosed as Carcinoma in situ and the other as PSCC. However, Russell et al. (20II) had also reported one patient who had two simultaneous lesions, one diagnosed with PSCC and the other with SCC (3). Similarly, Marques et al. (2009) reported a case presenting two exophytic nodular papillomatous lesions with white spots on the lateral border of the tongue (14).
PSCC lesions are usually exophytic, friable, papillomatous and between 0.5 and $6.5 \mathrm{~cm}$ in size $(3,6)$, agreeing with the case of this study. The subject in our study presented pain and 3 months of lesion evolution, contrasting with Russell et al. (20II), since $66.6 \%$ of the cases presented no pain a higher average lesion evolution time (10.7 months) (3). Smoking and drinking habits of this patient may be associated with the etiology of this disease $(2,3,7,17)$.

The main differential diagnoses for PSCC are Verrucous Carcinoma and SCC, which corroborates our initial clinical suspicion of SCC $(7,9,19)$. Thus, performing a histopathological analysis is fundamental for the correct diagnosis of PSCC ( I0). The tumor was staged as T3N2aM0 (IV-A), what corroborates some authors, who also identified lymph nodes involvement $(2,3,7)$ and advanced stages (3) at the time of diagnosis.

In initial stages (I and II), surgical excision, with or without lymph node dissection $(2,3,6,13,18)$ must be used, and may be associated with chemotherapy (9) and/or radiotherapy $(3,7,9)$. However, in advanced stages (III and IV), when surgery is not indicated, chemotherapy and radiotherapy can be recommended, as observed in this case. Despite the classic chemotherapy regimen of 3 cycles of $100 \mathrm{mg} /$ $\mathrm{m}^{2}$ cisplatin every 21 days, other schedules are possible, such as weekly cycles (20) as in this study.

After two years of follow-up, the patient showed no evidence of oral cavity disease, lymph nodes or distant metastases, corroborating the literature, that considers PSCC a tumor with a favorable prognosis, with a $70 \%$ survival in five years (2I). PSCC recurrences, however, are frequent (2-4,7,2 I), whereas distant metastases are uncommon (4), but neither was observed.

\section{CONCLUSION}

PSCC is a rare tumor in the oral cavity with few reported cases. Most cases were reported separately and those we presented were small and with retrospective diagnostic reviews. This case report emphasizes the importance of histopathological examination for the accurate diagnosis and its role in determining appropriate treatments and prognosis. 
The authors declare no conflicts of interest.

\section{Corresponding Author:}

Lísia Daltro Borges Alves

Department of Health Sciences, State University of Feira de Santana.

Transnordestina Avenue

Post Code: 44036-900, Feira de Santana, Bahia, Brazil.

Email: lisia_94@hotmail.com

\section{REFERENCES}

I. El-Naggar AK, Chan JKC, Grandis JR, Takata T, Slootweg PJ. World Health Organization Classification of Head and Neck Tumours. 4th ed. Lyon: International Agency for Research on Cancer (IARC); 2017.

2. Ding Y, Ma L, Shi L, Feng J, Liu W, Zhou Z. Papillary squamous cell carcinoma of the oral mucosa: a clinicopathologic and immunohistochemical study of 12 cases and literature review. Ann Diagn Pathol. 2013;17(1):18-21.

3. Russell JO, Hoschar AP, Scharpf J. Papillary squamous cell carcinoma of the head and neck: a clinicopathologic series. Am J Otolaryngol. 20 I 1;32(6):557-63.

4. Mehrad M, Carpenter DH, Chernock RD, Wang H, Ma X-J, Luo $Y$, et al. Papillary sqaumous cell carcinoma of the head and neck: Clinicopathologic and Molecular Features With Special Reference to Human Papilomavirus. Am J Surg Pathol. 20 | 3;37(9): | 349-56.

5. Terada T. Papillary squamous cell carcinoma of the oral cavity with acantholytic and pseudovascular features. Int I Clin Exp Pathol. 20 I 1:4(8):794-6.

6. TeradaT.Papillary squamous cell carcinoma of the mandibular gingiva. Int J Clin Exp Pathol. 20 I2;5(7):707-9.

7. Ishiyama A, Eversole LR, Ross DA, Raz Y, Kerner MM, Fu YS, et al. Papillary Squamous Neoplasms of the Head and Neck. Laryngoscope. 1994; 104: I 446-52.

8. Pereira F de AV, Ferreira C de AP, Penoni DC, Leão ATT. Periodontal Disease and Cancer: What is the Relationship? Nav Dent J. 2021;48(1):24-32.

9. Suarez PA, Adler-Storthz K, Luna MA, El-Naggar AK, AbdulKarim FW, Batsakis JG. Papillary squamous cell carcinomas of the upper aerodigestive tract: a clinicopathologic and molecular study. Head Neck. 2000;22(4):360-8.

10. Ferlito A, Devaney KO, Rinaldo A, Putzi MJ. Papillary squamous cell carcinoma versus verrucous squamous cell carcinoma of the head and neck. Ann Otol Rhinol Laryngol. 1999; | 08:318-22.

I I. Khan SM, Gossweiler MK, Zunt SL, Edwards MD, Blanchard SB. Papillary Squamous Cell Carcinoma Presenting on the Gingiva. J Periodontol. 2005;76(I 2):2316-21.

I2. Alotaiby F, Song F, Boyce B], Dengfeng CAO, Zhao Y, Lai J. Unusual papillary squamous cell carcinoma of the tip of tongue presenting in a patient status post heart transplant. Anticancer Res. 20 I8;38(7):4203-6.

13. Xiaofeng Q, Wei H. Papillary squamous cell carcinoma of the cheek. J Craniofac Surg. 2016;27(4):e4I6.

14. Marques YMFS, Chicaro CF, Tosta M, Kowalski LP, Pinto Jr D dos S. Papillary squamous cell carcinoma of the tongue. Otolaryngol Neck Surg. 2009; 141:298-9.

15. Takeda $Y$, Satoh M, Nakamura S, Yamamoto $H$. Papillary squamous cell carcinoma of the oral mucosa: immunohistochemical comparison with other carcinomas of oral mucosal origin. J Oral Sci. 200 I;43(3): I65-9.

16. Fitzpatrick SG, Neuman AN, Cohen DM, Bhattacharyya I. Papillary Variant of Squamous Cell Carcinoma Arising on the Gingiva: 6I Cases Reported from Within a Larger Series of Gingival Squamous Cell Carcinoma. Head Neck Pathol. 2013;7(4):320-6.

17. Bao Z,Yang X, Shi L, Feng J, Liu W, Zhou Z. Clinicopathologic features of oral squamous papilloma and papillary squamous cell carcinoma: A study of 197 patients from eastern China. Ann Diagn Pathol. 20 12;16(6):454-8.

I 8. Jo VY, Mills SE, Stoler MH, Stelow EB. Papillary Squamous Cell Carcinoma of the Head and Neck Frequent Association With Human Papillomavirus Infection and Invasive Carcinoma. Am J Surg Pathol. 2009;33(I I):1720-4.

19. Batsakis JG, Suarez P. Papillary squamous cell carcinoma:Will the real one please stand up? Adv Anat Pathol. 2000;7(1):2-8. 20. De Felice F, Belgioia L, Alterio D, Bonomo P, Maddalo $M$, Paiar $F$, et al. Survival and toxicity of weekly cisplatin chemoradiotherapy versus three-weekly cisplatin chemoradiotherapy for head and neck cancer: A systematic review and meta-analysis endorsed by the Italian Association of Radiotherapy and Clinical Oncology (AIRO). Vol. 162, Critical Reviews in Oncology/Hematology. Elsevier Ireland Ltd; 2021. p. 103345.

21. Thompson LD. Squamous cell carcinoma variants of the head and neck. Curr Diagnostic Pathol. 2003;9(6):384-96. 